\title{
All roads lead to Rome? Frechulf of Lisieux, Augustine and Orosius
}

\author{
GRAEME WARD
}

This article considers the influence exerted by Augustine's City of God and Orosius's Histories against the Pagans on the Carolingian historian, Frechulf of Lisieux. In particular, it explores how these two explicitly Roman texts were read and understood in the ninth century, and how they in turn shaped the place of Rome and its empire within Frechulfs narrative. In the first half of this article, I shall take into account modern discussions of Augustine and Orosius, which themselves have shaped scholarship on Frechulf. The second half of the article stresses that for Frechulf, Augustine and Orosius offered complementary, not contradictory perspectives on Christian history and Rome's part in it.

\section{Introduction}

By around 830, during the reign of the Carolingian emperor Louis the Pious, Frechulf, bishop of the northern Frankish see of Lisieux, completed his Histories. ${ }^{\text {I }}$ Frechulf composed his vast account of human history in two separate but coherent volumes. Part I, which was dedicated to Helisachar, a prominent member of Louis's imperial entourage, covered the period between the creation of Adam and the birth of Christ. Part II, offered to the Empress Judith for the education of her young son Charles, took the story forward from the Nativity to the turn of the seventh century, when the Franks and Lombards replaced the Goths and Romans as rulers of Gaul and Italy. Frechulfs universal history had a decidedly western, post-Roman conclusion. It 'defined a new geography

* I should like to thank Rosamond McKitterick, Molly Lester, Rutger Kramer and Marianne Pollheimer for their very helpful comments and suggestions, and the OeAD for the award of an Ernst Mach Stipendium, which enabled me to write this article.

I On Frechulf's life, see M.I. Allen, Prolegomena, CCCM I69 (Turnhout, 2002), pp. II*-I8*. On Louis's reign, see M. de Jong, The Penitential State: Authority and Atonement in the Age of Louis the Pious, 8I4-840 (Cambridge, 2009), ch. I. 
still occupied by Carolingian readers', ${ }^{2}$ whilst helping to connect them with the Christian past and the authoritative textual resources in which it was contained.

Frechulf compiled his Histories by weaving together excerpts from such resources into a new compendious Christian whole. The majority of these texts were Roman, to the extent that they were written by people living in the Roman empire, or concerned figures and events that pertained to educated Romans. ${ }^{3}$ Two of Frechulf s sources in particular have attracted attention: Augustine's City of God (written by c.427) and Orosius's Seven Books of History against the Pagans (written c.4I7).

These two influential texts, frequently read together today, were also considered alongside one another by Frechulf. Towards the end of the second volume of the Histories, there is a short chapter about the translation of the relics of St Stephen from the Greek east to the Latin west. ${ }^{4}$ The Spanish priest Orosius, who at the recommendation of Augustine had been studying in the Holy Land with Jerome, was entrusted with the task of transporting the relics. This snippet of biographical information was first recorded in the fifth century by Gennadius of Marseilles in his continuation of Jerome's De viris illustribus, and then in the eighth century it was incorporated by Bede into the influential world chronicle that he embedded within his De temporum ratione, from where Frechulf gleaned it. 5 To this widely known nugget, however, Frechulf offered his own elaboration. Augustine, the 'extraordinary doctor [of the Church]', had in his 'books about the City of God' mentioned the many miracles that God had carried through Stephen's relics when they arrived in North Africa, before digressing further to note that, according to a certain other doctor (that is, Isidore), Augustine wrote so many works that anyone who claimed to have read them all was surely lying. Finally Frechulf concluded this chapter by stating that it was at Augustine's behest that Orosius, his pupil (discipulus), 'nobly and usefully composed seven books against the pagans'. ${ }^{6}$

M.I. Allen, 'Frechulf of Lisieux', in K. Pollmann and W. Otten (eds), The Oxford Guide to the Historical Reception of Augustine, 3 vols (Oxford, 2013), II, pp. IoIo.

On Frechulf's sources, Allen, Prolegomena, pp. 200*-19*. Roman sources: P. Chiesa, 'Storia romana e libri di storia romana fra IX e XI secolo', in Roma antica nel Medioevo: mito, rappresentazioni, sopravvivenze nella 'Respublica Christiana' dei secoli IX-XIII (Milan, 20oI), pp. 232-58, at pp. 242-7. M. Vessey, 'Reinventing History: Jerome's Chronicle and the Writing of the post-Roman West', in S. McGill, C. Sogno and E. Watts (eds), From the Tetrarchs to the Theodosians: Later Roman History and Culture, 284-450 CE (Cambridge, 2010), pp. 265-89. On Roman texts in the early Middle Ages, see Rosamond McKitterick's contribution to this issue. Frechulf of Lisieux, Histories II.5.I2, ed. M.I. Allen, CCCM I69 A (Turnhout, 2002), pp. 594-5. Gennadius of Marseilles, Liber de viris illustribus, c. 40, ed. E.C. Richardson, Texte und Untersuchungen zur Geschichte der altchristlichen Literatur I4 (Leipzig, I896), p. 76; Bede, De temporum ratione liber, c. 66, ed. C.W. Jones, CCSL I23 B (Turnhout, I977), p. 5I4.

6 Frechulf, Histories II.5.I2 [I8.19], p. 695: 'Illo etiam iubente Horosius, discipulus eius praedictus, libros septem Adversus gentes nobiliter et utiliter composuit.' 
This remarkable passage provides a glimpse into Frechulf's knowledge of both the City of God and Histories against the Pagans. Frechulf knew from Orosius's prologue and epilogue that his text was tied to the authority of Augustine, whom Orosius stated had ordered that the work be written. ${ }^{7}$ This fact would have been widely known, considering the number of complete manuscripts of Orosius that were copied in the early Middle Ages, yet no author before Frechulf had explicitly made this connection in their own writings. ${ }^{8}$ Uniquely, Frechulf also joined the dots between Augustine's discussion of miracles in the final book of the City of God and the more commonly quoted biography of Orosius. Less immediately apparent is how the two texts functioned together within the body of Frechulf s text itself.

Jocelyn Hillgarth noted that during the Middle Ages 'Orosius benefited very greatly ... from the general assumption that his Historiae was an indispensable complement to the City of God', but since the nineteenth century his work 'has suffered correspondingly from a comparison between his work and that of Augustine.' In particular, historians in the twentieth century have drawn attention to Augustine's and Orosius's conflicting perceptions of the significance of the Roman empire within Christian history. ${ }^{\text {IO }}$ For Orosius, the argument runs, the Christian Roman empire marked the culmination of all history, the fourth and final world monarchy divinely ordained to rule the earth until its very end: 'the unique civil and political entity of Rome, where the earthly existence of Christianity was conceivable, constituted the supreme, final phase of history'. ${ }^{I I}$ Orosius saw the Roman empire 'as almost the instantiation of heaven upon earth', or at least he felt 'that Christian Rome will certainly

Orosius, Historiae adversus paganos I. Prol., ed. M.-P. Arnaud-Lindet, 3 vols (Paris, I990-I), I, pp. 6-9 and VII.43.19-20 (III, p. 132). P. van Nuffelen, Orosius and the Rhetoric of History (Oxford, 20I2), pp. 3, 23, 3I-4I.

8 E. Brilli, 'L'entente entre Orose et saint Augustin. Contribution à l'étude de la réception médiévale des Historiae', Sacris Erudiri 5I (2012), pp. 363-90, at pp. 372-3. On the manuscripts of Orosius, see L.B. Mortensen, 'The Diffusion of Roman Histories in the Middle Ages. A List of Orosius, Eutropius, Paulus Diaconus, and Landolfus Sagax', Filologia Mediolatina 6-7 (I999-2000), pp. IOI-200.

9 J.N. Hillgarth, 'The Historiae of Orosius in the Early Middle Ages', in L. Holtz and J.-C. Fredouille (eds), De Tertullien aux Mozarabes: mélanges offerts à Jacques Fontaine, à l'occasion de son 7oe anniversaire, par ses élèves, amis et collègues, 2 vols (Paris, I992), II, pp. I57-70, at p. I57. For a historiographical overview, Peter van Nuffelen, Orosius and the Rhetoric of History (Oxford, 20I2), pp. 5-9.

to For a classic statement, see R.A. Markus, 'The Roman Empire in Early Christian Historiography', Downside Review 8I (1963), pp. 340-53, at p. 352.

" G. Zecchini, 'Latin Historiography: Jerome, Orosius and the Western Chronicles', in G. Marasco (ed.), Greek and Roman Historiography in Late Antiquity: Fourth to Sixth Century A.D. (Leiden, 2003), pp. 317-45, at p. 324. 
bring heaven closer to earth'. ${ }^{12}$ Orosius's historical approach looked back, even 'regressed', to the Christian imperial triumphalism of Eusebius of Caesarea, with whom he is frequently compared; it had little in common with the more mature and sophisticated beliefs of Orosius's teacher. ${ }^{13}$ Augustine, as Robert Markus stressed, drained the Roman empire of any sacred significance and accorded it no special role within the history of salvation. It was, in short, rendered 'theologically neutral'. ${ }^{14}$ As a result, Orosius and Augustine have often been deemed thoroughly antithetical and fundamentally incompatible with one another. ${ }^{15}$ Between the authors stood a 'deep gulf', an 'abyss'. ${ }^{16}$ The Histories against the Pagans has been described as an 'anti-De civitate Dei. ${ }^{17}$ In the same vein, parts of Augustine's City of God have been described as a 'contra Orose'. ${ }^{18}$

Recent scholarship on Orosius, however, has sought to explore cultural commonalities rather than highlight contrasts between the Histories against the Pagans and the City of God. ${ }^{19}$ The sack of Rome by Alaric's Goths in August 4IO provided the initial impetus for both, and thus both texts shared the same basic purpose: to convince Roman readers that the Gothic sack had nothing to do with the weakness of the Christian religion to guarantee the security of the Roman state. Whereas Augustine focused his attention on undermining the authority of old Roman gods and the validity of ancient philosophy, Orosius sought to destabilize the heroic status of classical antiquity and of Roman literature by highlighting the wretchedness of the pre-Christian past in comparison with the tempora Christiana. In their own very different ways, both works were rhetorically charged Christian apologies, directed against 'pagans', or at

${ }_{12}$ A.T. Fear, 'Introduction', in Orosius: Seven Books of History against the Pagans (Liverpool, 2010), pp. 2I, 23.

13 T.E. Mommsen, 'Augustus and Orosius', in E.F. Rice Jr (ed.), Medieval and Renaissance Studies (Ithaca, NY, 1959), pp. 325-48; H.I. Marrou, 'Saint Augustin, Orose et l'augustinisme historique', Settimane 17 (1970), pp. 59-87; H.-W. Goetz, Die Geschichtstheologie des Orosius, Impulse der Forschung 32 (Darmstadt, 1980), pp. 136-47; Hervé Inglebert, Les romains chrétiens face a l'histoire de Rome: histoire, christianisme et romanités en Occident dans l'Antiquité tardive (III ${ }^{e}-V^{e}$ siècles) (Paris, 1996), pp. 507-89. See, however, van Nuffelen, Orosius, pp. 19I-7.

${ }_{14}$ R.A. Markus, Saeculum: History and Society in the Theology of St Augustine, rev. edn (Cambridge, I988), pp. 54-5.

is M. Meier and S. Patzold, August 4Io: ein Kampf um Rom (Stuttgart, 2010), p. 63.

${ }_{16}$ Markus, Saeculum, p. I66; Brilli, 'L'entente', p. 365.

${ }_{17}$ G. Zecchini, 'Latin Historiography: Jerome, Orosius and the Western Chronicles', in G. Marasco (ed.), Greek and Roman Historiography in Late Antiquity: Fourth to Sixth Century A.D. (Leiden, 2003), pp. 317-45, at p. 329.

${ }_{18}$ Inglebert, Romains chrétiens, pp. 485-94, discussing Book XVIII of De civitate Dei.

19 Van Nuffelen, Orosius and the Rhetoric of History (Oxford, 2012) and M. Formisano, 'Grand Finale. Orosius' Historiae adversus paganos, or the Subversion of History', in H. Harich-Schwarzbauer and K. Pollmann (eds), Der Fall Roms und seine Wiederauferstehungen in Antike und Mittelalter, Millenium-Studien 40 (Berlin, 2013), pp. I53-76. 
least those who still looked favourably and nostalgically upon classical Roman culture. $^{20}$

Augustine and Orosius both produced conspicuously Roman texts, written by Romans for Romans. ${ }^{21}$ When singing the praises of the empire of his own day, Orosius even underlined that he found safe haven when he came to North Africa because he came 'as a Roman and Christian to Christians and Romans'. ${ }^{22}$ Frechulf stood at a great distance from the political and cultural milieu of the early fifth century. He wrote in a post-Roman empire, in which classical Rome did not represent an ideal or rival cultural system that needed to be undermined. The immense... cultural gulf which separated the Mediterranean world of the patristic period from that of Carolingian Francia' was arguably more significant than the supposed 'abyss' separating Augustine and Orosius. ${ }^{23}$ From his ninth-century vantage point, Frechulf looked back upon the Roman empire through specific texts that were available to him. This is an obvious but important point.

What did Frechulf see in his sources? On the one hand, there was didactic material. As he expressed in the prologue to Judith, the heroes and villains who lived during the Roman empire constituted a wealth of examples from which young Charles could learn important lessons in Christian leadership. ${ }^{24}$ Such exempla, however, were embedded within a larger narrative, the core of which was summed up at the very beginning of the Histories. Helisachar, Frechulf explained, had implored that he exert himself 'by hunting diligently through the volumes of the ancients, of both sacred and secular writers, and to collect briefly and clearly everything that pertained to the truth of the history.'. ${ }^{25}$

In looking to understand the shape, structure and emphases of the Histories, scholars have focused less on the 'truth of history' and more on

20 Van Nuffelen, Orosius, pp. I5-I8 and K. Pollmann, 'Nullus quippe credit aliquid, nisi prius cogitaverit esse credendum: Augustine as Apologist', in A.-C. Jacobsen, J. Ulrich and D. Brakke (eds), Critique and Apologetics: Jews, Christians and Pagans in Antiquity, Early Christianity in the Context of Antiquity 4 (Frankfurt am Main, 2009), pp. 303-27.

${ }_{21}$ On Augustine, see N. McLynn, 'Augustine's Roman Empire', in M. Vessey, K. Pollmann and A.D. Fitzgerald (eds), History, Apocalypse and the Secular Imagination (Bowling Green, $\mathrm{OH}$, 1999), pp. 29-44.

22 Orosius, Historiae V.2.3, ed. Arnaud-Lindet, II, p. 86; trans. A.T. Fear, Orosius: Seven Books of History against the Pagans (Liverpool, 20I0), p. 209.

23 J.J Contreni, 'Carolingian Biblical Studies', in U.-R. Blumenthal (ed.), Carolingian Essays: Andrew W. Mellon Lectures in Early Christian Studies (Washington, 1983), pp. 7I-98, at p. 9I.

24 G. Ward, 'Lessons in Leadership: Constantine and Theodosius I in Frechulfs Histories', in R. McKitterick, S. Meeder and C. Gantner (eds), The Resources of the Past in Early Medieval Europe (Cambridge, forthcoming).

${ }_{25}$ Frechulf, Histories I, Prol., ed. Allen, p. I8: 'iussisti [Helisachar] ut perscrutando diligenter uolumina antiquorum, seu agiographorum siue etiam gentilium scriptorum, quaeque pertinent ad historiae ueritatem breuiter ac lucide colligere desudarem'. E. Mégier, 'L'histoire biblique pré-abrahamique est-elle un sujet pour les historiens? S. Jérôme, S. Augustin et les critères d'historicité dans les historiae de Fréculphe de Lisieux', in R. Berndt and M. Fédou (eds), Les 
influence exerted by particular sources used by Frechulf, not least Augustine and Orosius. In the late nineteenth century, Adolf Ebert stated that the City of God and the Histories against the Pagans were 'the works which had the greatest influence on the arrangement and execution of [Frechulf s] world chronicle'. ${ }^{26}$ This influence has often been assessed in the light of Frechulf's adoption or omission of the six Augustinian 'ages of the world' and the four 'world monarchies' of Orosius. ${ }^{27}$

More recently, the influence of Augustine has been judged to be the more significant. In a still-seminal article, Nikolaus Staubach argued that Frechulf constructed the whole dynamic of his work around the central theme of the City of God: the confrontation between the civitas Dei and civitas terrena, between the members of the earthly and heavenly cities. Frechulf traced this confrontation from Cain's murder of Abel in the very first book of his Histories, from which both cities then grew, right through to his work's seventh-century conclusion. ${ }^{28}$ Michael Allen has added extra nuance to Frechulf's reception of Augustine and also discovered that much of the 'Augustinian' material was derived indirectly through Claudius of Turin's early ninth-century Genesis commentary. ${ }^{29}$ Yet whether accessed directly or indirectly, Frechulf has been judged nevertheless to have made Augustine's 'choice-laden sociology of heavenminded versus earth-bound humanity the cornerstone of his vision'..$^{30}$

Whilst not seeking to deny the importance that Augustine's two cities play at the beginning of the Histories, we need not give this absolute pride of place in our interpretations of Frechulf. Carolingian scholars frequently 'drew on their sources interchangeably, filling in the gaps of tradition with whatever was available in order to bring their reader to the fullest understanding of the topic at hand'. ${ }^{3 \mathrm{I}}$ Augustine was a towering

réceptions des Pères de l'Église au Moyen Âge: le devenir de la tradition ecclésiale, 2 vols, Archa Verbi: Yearbook for the Study of Medieval Theology Io (Münster, 2013), II, pp. I057-73, esp. pp. I064-9.

26 A. Ebert, Allgemeine Geschichte der Literatur des Mittelalters im Abendlande, 2 vols (Leipzig, I880), II, p. 383: 'Augustins Civitas dei und Orosius' Geschichte . . . sind die Werke, welche auf die Anlage und Ausführung dieser Weltchronik den größsten Einfluss gehabt haben.'

${ }_{27}$ M. Innes and R. McKitterick, 'The Writing of History', in R. McKitterick (ed.), Carolingian Culture: Emulation and Innovation (Cambridge, 1994), pp. 193-220, at p. 2I2. Cf. M.I. Allen, 'Universal History 300-I000: Origins and Western Developments', in Deborah Mauskopf Deliyannis (ed.), Historiography in the Middle Ages (Leiden, 2003), pp. 17-42, at pp. 26-32, 40-I.

28 N. Staubach, 'Christiana tempora: Augustin und das Ende der alten Geschichte in der Weltchronik Frechulfs von Lisieux', Frühmittelalterliche Studien 29 (1995), pp. 167-206, esp. pp. I82-90.

29 Allen, 'Frechulf of Lisieux', pp. IoIo-II; Allen, 'Universal History', pp. 39-40; Allen, Prolegomena, pp. $205^{*}-6^{*}$.

30 Allen, 'Frechulf of Lisieux', p. IoII.

35 M. Ponesse, 'Standing Distant from the Fathers: Smaragdus of Saint-Mihiel and the Reception of Early Medieval Learning', Traditio 67 (2012), pp. 7I-99, at p. 78. 
authority, but one of many with which Frechulf was armed in his search for the 'truth of history'. Thus, it may be significant that almost all of the Augustinian elements are to be found in Frechulfs first book, which is arguably the most unusual of the whole work, seeing as it covered pre-Abrahamic history, to some extent a gap period in the tradition of Christian historiography. ${ }^{32}$

Situating Augustine at the centre of Frechulf s Histories, furthermore, has shaped interpretations of how Frechulf read Orosius. This, it seems, stems from the dichotomy, summarized above, that modern scholars have created between Augustine and his discipulus. Indeed, it has been suggested that Frechulf was the better student of Augustine, and that unlike the Spanish presbyter, Frechulf 'did not equate the Roman Empire with the City of God'. ${ }^{33}$ Allen has likewise stressed that '[a]lthough he incorporates much of Orosius' Histories against the Pagans, F[rechulf] excludes the quintessentially Orosian political exegesis that Augustine himself rejected' in his De civitate Dei. ${ }^{34}$ Frechulf, furthermore, 'did not embrace the far more usual Orosian expedient of equating either [of the two cities] with some conventional political fellowship'. ${ }^{35}$

Such arguments imply that Frechulf read Orosius and Augustine as modern scholars frequently have. Did Frechulf see in the City of God and the Histories against the Pagans conflicting accounts of the sacred significance of the Roman empire, which he adjusted accordingly, or even as two texts containing radically different Geschichtstheologien? How readily can modern discussions about Augustine and Orosius be mapped on to later, medieval, evidence ${ }^{36} \mathrm{~A}$ full study of these issues is not possible here; rather, by examining Frechulf's Histories, I wish to consider in more detail the significance of Rome and the empire within the work of one

32 See Mégier, 'L'histoire biblique pré-abrahamique'.

33 T.F.X. Noble, Images, Iconoclasm and the Carolingians (Philadelphia, 2009), p. 353; Staubach, 'Christiana tempora', pp. I83-4, I98-9.

34 Allen, 'Frechulf of Lisieux', p. IoIo. Cf. Augustine, De civitate Dei XVIII.52, ed. B. Dombart and A. Kalb, 2 vols, CCSL 47-8 (Turnhout, I955), II, pp. 650-2.

35 Allen, 'Frechulf of Lisieux', p. IOIr. See also Allen, 'Universal History', p. 4I; Allen, Prolegomena, p. $24^{*}$.

36 On the reception of Orosius, see for example Goetz, Geschichtstheologie, pp. I48-63; Y. Coz, 'Quelques interprétations des Historiae adversum paganos d'Orose au IX ème siècle', Journal of Medieval Latin 17 (2007), pp. 286-99; H. Eisenhut, Die Glossen Ekkeharts IV. Von St Gallen im Codex Sangallensis 62I, Monasterium Sancti Galli 4 (St Gallen, 2009), pp. 49-104, and review by Michael I. Allen, in Journal of Medieval Latin 23 (2013), pp. 346-53; Richard Corradini's contribution to this issue. On Augustine, in addition to the Oxford Guide to the Historical Reception of Augustine, both J.J. Contreni, 'Carolingian Era, Early', in Allan D. Fitzgerald (ed.), Augustine through the Ages: An Encyclopedia (Cambridge, 1999), pp. I24-9, and B.M. Kaczynski, 'Reading and Writing Augustine in Medieval St Gall', in G.R. Wieland, C. Ruff and R.G. Arthur (eds), Insignis sophiae arcator: Essays in Honor of Michael W. Herren on his 65th Birthday, Publications of the Journal of Medieval Latin 6 (Turnhout, 2006), pp. I07-23 are helpful. 
Carolingian intellectual, together with some of the ways in which Augustine and Orosius contributed to it. ${ }^{37}$

\section{Rome and Babylon}

Frechulf began the second book of Part I by describing the world into which Abraham was born. At that time, the Assyrians, under the leadership of Ninus, were the most powerful of the world's kingdoms. Frechulf stated that Babylon, the head of the Assyrian realm, meant 'confusion', a name 'most apt for the city of the earth-born'. Rome, founded I200 years later, was itself then referred to 'as another Babylon in the west' (alteram in Occidente Babylloniam). This was an ostensibly Augustinian sentiment, gleaned straight from the pages of the City of God. ${ }^{38}$

When Frechulf later came to the founding of Rome in his third book, the city was again through the words of Augustine labelled a 'western Babylon' (occidentalis Babylon). Rome's foundation coincided with Assyria's fall, yet this parallel contained even more deeply seated significances. Engaging with the City of God, Frechulf noted that at this time a song of the Erythraean Sibyl, 'which the blessed Augustine translated from Greek into the Latin language' ('quae beatus Agustinus [sic] ex Greco in Latinum vertit eloquium'), spoke 'openly about Christ', for it contained an acrostic that spelled out 'Jesus Christ, son of God, the Saviour'. ${ }^{39}$ At this time, moreover, many Jewish prophets 'erupted together, as it were, like fountains of prophecy ('velut fontes prophetiae eruperunt pariter'), when the kingdom of the Assyrians perished and that of the Romans began'. Clearly for Frechulf, the ties between Babylon and Rome ran deep. Abraham's promises to the Gentiles, which were uttered 'in the first days of the Assyrian empire', were to be fulfilled with Christ's advent; with the founding of Rome, 'during whose rule Christ was to come' ('qua fuerit Christus imperante venturus'), there was a significant outpouring of prophecy. More than before, these prognostications were considered to pertain more obviously to the gentes than the Jews themselves. '[I]t was fitting', therefore, 'that this should occur at the same time as the foundation of that city which was to rule all the Gentiles. ${ }^{40}$

I hope to develop some of the points raised here much more fully in subsequent work.

${ }^{38}$ Frechulf, Histories I.2.I, ed. Allen, p. 9I, excerpting from Augustine, De civitate Dei XVI.I7, ed. Dombart and Kalb, II, p. 522; trans. from R.W. Dyson, Augustine: The City of God against the Pagans (Cambridge, 1998), p. 725. Cf. Staubach, 'Christiana tempora', p. I87; Noble, Images, p. 353.

39 Frechulf, Histories I.3.I2, ed. Allen, pp. 176-7. See also I.3.I2. cap., p. I56.

40 Frechulf, Histories I.3.I2, ed. Allen, pp. 175-6; Augustine, De civitate Dei XVIII.27, ed. Dombart and Kalb, II, p. 618; trans. Dyson, City of God, p. 856. See also Augustine, De civitate Dei XVIII.22, ed. Dombart and Kalb, II, pp. 6r2-13. 
Yet the association between Rome and Babylon was not exclusively Augustinian, and quoting from the City of God need not mean that Frechulf adopted a specific, clearly defined 'theology of history'. The comparative fortunes of these two cities also formed the central spine of Orosius's Histories against the Pagans. ${ }^{4 \mathrm{I}}$ Equipped with Orosius as well as Augustine, Frechulf knew not only that the end of the Assyrian empire coincided with the foundation of Romulus's new city, but also that the fall of Babylon at the hands of the Persians coincided with the beginning of the Roman republic. After providing a very brief survey of Babylonian history between the city's foundation under the Assyrians and its conquest by the Persian king Cyrus, Frechulf paused to offer his own reflection:

Certainly, I recall now that the apostle Peter quite rightly called Rome 'Babylon' in his writings (I Pt V.I3), since while Babylon was first made head of the world and held it firm up until Sardanapallus, who after being killed lost most of his power, nevertheless the Chaldeans, who punished their enemies the Medes, retained some of the kingdom. At which time, Procas, uncle of Rhea Silvia, who was the mother of Romulus, began to rule, from whom the histories of the Romans begin: from whom the seed of Rome was sown, although the sprouts were not yet visible. But Babylon at that time came to an end, having been overthrown by Cyrus, when Rome was first liberated from the domination of Tarquin kings. So it was at this exact conjunction of time that the one in the East fell and the other in the West rose. The former suffered the heel of domination for the first time, while the latter threw off the haughty rule of her masters for the first time. The former, like a dying man, abandoned its inheritance, the latter, though but a youth, recognised itself as its heir. It was at this time that the Empire of the East perished and that of the West arose. Rome was rightly called Babylon by the apostle. ${ }^{42}$

${ }^{41}$ Van Nuffelen, Orosius, pp. 46-53. Comparing Augustine and Orosius: Inglebert, Les romains chrétiens, pp. 486-9; H. Bellen, 'Babylon und Rom - Orosius und Augustinus', in P. Kneissl and V. Losemann (eds), Imperium Romanum: Studien zu Geschichte und Rezeption. Festschift für Karl Christ zum 75. Geburstag (Stuttgart, 1998), pp. 5I-60; A.H. Merrills, History and Geography in Late Antiquity (Cambridge, 2005), pp. 54-5. See also Rosamond McKitterick's contribution to this issue.

${ }^{42}$ Frechulf, Histories I.3.I7, ed. Allen, p. I92: 'Enimuero non inmerito beatum apostolum Petrum Romam in suis scriptis Babylloniam nominasse nunc recolo, quoniam dum in Oriente prima caput orbis est effecta Babyllon mansit que inconcussa usque ad Sardanapallum, quo interfecto amisit partem maximam potentiae, tamen partem regni paenes se retinuerunt Chaldei, qui Babylloniam sibi aduersum Medos uindicauerunt. Quo in tempore Procha, auus Reae Siluiae, quae mater Romuli fuit, regnare coepit, a quo historiae Latinorum inchoantur: ab eo enim sementum Romae iactum, quamuis nondum germen appareret. Babyllon uero nouissime eo tempore a Cyro rege subuersa quo primum Roma a Tarquiniorum regum dominatione liberata 
Frechulf took much of this passage from Orosius, but adopting his own voice (recolo), he framed it explicitly around scriptural authority. The link between Babylon and Rome was attributed neither to Augustine nor Orosius, but to Peter the Apostle, who at the end of his first Epistle had written: 'She who is in Babylon, chosen together with you, sends you her greetings, and so does my son Mark.' Patristic exegesis of this verse, preserved within sources such as Rufinus's translation of Eusebius's Ecclesiastical history and Jerome's De viris illustribus, both of which Frechulf drew upon extensively in the second volume of his Histories, underlined that Peter referred figuratively to Babylon as Rome. ${ }^{43}$ This rare interjection by Frechulf offers a very valuable glimpse onto the thick layers of Christian learning upon which his Histories were built.

\section{Christ and Augustus}

The association between Rome and Babylon was thus both Augustinian and Orosian, yet Frechulf used both texts to shed light on the more important narrative which underpinned them: the grand narrative of Christian history that was rooted in Scripture. At the heart of this narrative lay the Nativity, which marked the main juncture within the whole of Frechulf s work, both dividing and unifying Parts I and II. The centrality of Christ to Christian history may not at first glance appear at all surprising, but Frechulf was the first historian to have split his narrative into two distinct halves: before and after Christ. It could be argued that Frechulf's use of the two cities in his first books was important because it connected the history of mankind between Adam and Christ, but this was especially so for the pre-Abrahamic period. ${ }^{44}$ From Abraham onwards, Frechulf traced the histories of the most powerful successive gentile kingdoms - that is, of the kingdoms of Assyria, Persia, Greece, and finally Rome - in relation to the history of the Jewish people (populus

est. Siquidem sub una eadem que conuenientia temporum illa in Oriente cecidit, ista in Occidente surrexit: illa tunc quasi moriens dimisit hereditatem, alienorum perpessa dominatum, haec uero pubescens se agnouit heredem, aspernata etiam suorum fastigium. Tunc Orientis occidit, et ortum est Occidentis imperium. Qua de re ab apostolo Roma iure Babyllon nuncupatur.' Trans. adapted from Fear, Orosius, pp. 74-5.

${ }^{43}$ Jerome, De viris illustribus, c. 8, ed. E.C. Richardson, p. I2: 'meminit huius marci et petrus in prima epistula, sub nomine babylonis figuraliter romam significans'; Eusebius-Rufinus, Historia ecclesiastica II.I5.2, ed. Eduard Schwartz and Theodor Mommsen, Die griechisch-christlichen Schriftsteller der ersten drei Jahrbundert 9, 3 vols (Berlin, 1903-1909), I, p. I4I: 'meminerit Marci, in qua tropice Romam Babylonam nominarit'. On these sources in the ninth century, R. McKitterick, History and Memory in the Carolingian World (Cambridge, 2005), pp. 22I-33, $235-44$.

44 See Frechulf, Histories I.r.9, ed. Allen, p. 36 and I.I.32, pp. 63-4. 
Dei). ${ }^{45}$ History followed its divinely steered course towards the coming of Christ, during which the power of Old Israel, although once great, declined and fell whilst Rome grew to such an extent that under Augustus the whole world was subjected to its rule. Christ stood at the nexus of these two narrative threads and in the minds of Christian intellectuals his advent shaped and determined them. ${ }^{46}$

Frechulf laid great emphasis on the birth of Christ and the providential role which Augustus, the first ruler who 'obtained the monarchy of the world', played in facilitating it. ${ }^{47} \mathrm{He}$ did so through extensive verbatim excerpts from the Histories against the Pagans. When Augustus first symbolically closed the gates of Janus on the 6 January and received his eponymous title, it coincided with what was to be Christ's Epiphany. ${ }^{48}$ Augustus, moreover, closed the gates of Janus for a third time after subduing the entire world and set it at peace. ${ }^{49}$ Just like Orosius, however, Frechulfs real focus was not Augustus:

Now at that time, namely in the year when Caesar, through God's decree, had established the most secure and stable peace on earth, Christ, for Whose coming that peace was a servant and upon Whose birth angels exultantly sang to listening men, 'Glory to God in the Highest, and on Earth peace towards men of good will', was born (Luke II.I4)..$^{\circ}$

Christ was born when the world became Roman, having been subjected to an extensive rule unparalleled in human history. ${ }^{5 \mathrm{I}}$ In a later chapter, when recording again the length of Augustus's reign and the extent of his empire, Frechulf stated explicitly that these things had been ordained entirely in order to prepare the way for the Nativity. ${ }^{52}$

45 Frechulf, Histories I, Prol., ed. Allen, pp. I8-I9 and I.2, Prol., pp. 85-6.

${ }^{46}$ On Frechulf s account of Jewish history, see R. McKitterick and G. Ward, 'Knowledge of Jewish History in the Early Middle Ages', in Y. Hen, O. Limor and T.F.X. Noble (eds), Barbarians and Jews: Jews and Judaism in the Early Medieval West (forthcoming).

${ }_{47}$ Frechulf, Histories II.I.2, ed. Allen, pp. 44I-2: 'Octovianus (sic) Caesar ... qui primus monarchiam obtinuit mundi.'

$4^{8}$ Frechulf, Histories I.7.I6, ed. Allen, pp. 4I3-I4.

49 Frechulf, Histories I.7.I6, ed. Allen, p. 4I7.

so Frechulf, Histories I.7.I6, ed. Allen, pp. 4I7-I8: 'Igitur eo tempore, id est eo anno quo firmissimam uerissimam que pacem ordinatione Dei Caesar conposuit, natus est Christus, cuius aduentui pax ista famulata est. In cuius ortu audientibus hominibus exultantes angeli cecinerunt Gloria in excelsis Deo, et in terra pax hominibus bonae uoluntatis'; trans. Fear, Orosius, p. 316. Cf. van Nuffelen, Orosius, pp. 195-7.

${ }^{51}$ Frechulf, Histories I.7.I6, ed. Allen, p. 4I8: 'Quod penitus numquam ab orbe condito atque ab exordio generis humani in hunc modum actum est.'

52 Frechulf, Histories II.I.4, ed. Allen, pp. 446-7: 'Qui certe numquam aut rei publicae potentiam ad se traxisset aut tamdiu ea potiretur nisi pro causa nativitatis Domini hoc fieret.' 
Frechulf began the second volume of his Histories by repeating and re-emphasizing the providential role of Augustus's empire, but this time in his own words. All the world's kingdoms had fallen 'under a single power', and such a situation,

which had never previously existed anywhere, came about not by the strength or wisdom of men, but by the omnipotence of God, something the prophet predicted long before, saying 'nation shall not lift sword against nation', and those things which follow. (Isaiah II.4) And thus it was fitting that when he who is the one God in the substance of the father and Holy Spirit, was born, the whole world was placed under a single census. And so this birth was celebrated, having been predicted by the prophets and proclaimed by the angels: 'Glory to God in the Highest and on Earth peace towards men of good will' (Luke II.I4), when the whole world rested under one peace in a miraculous manner, unheard of in the preceding ages. Not only did the sacred writings predict this birth and peace long ago, but so too did the pagan oracles, as they are contained in the Sibylline books and in other songs..$^{53}$

This passage demonstrates how Frechulf had absorbed one of the central arguments of Orosius's Histories against the Pagans; he made his own notable additions, however. The peace which Augustus's empire engendered fulfilled not only Luke II.I4, as Orosius underscored, but also Isaiah II.4. Jerome, in his Commentary on Isaiah, had argued already for this. ${ }^{54}$ Frechulf also connected Christ's birth back to 'sacred writings' and the 'Sibylline books' that predicted it. In the context of his Histories, this harked back to the predictions about Christ and the church made by renowned figures such as Abraham, ${ }^{55}$ but also to the fountain of prophecy that 'erupted' as Assyria fell and Rome was born. Frechulf then returned

53 Frechulf, Histories II.I.2 [I/I8], pp. 440-I: 'in unius ditionis pariter omnia conciderunt regna. Et hoc non hominum fortitudo uel prudentia, sed Dei omnipotentia, quod antea nusquam fuerat, praeparauit, quod longe ante propheta praeuidens ait: Non leuabit gens contra gentem gladium, et quae sequuntur. Dignum itaque erat ut illo nascente qui unus est Deus in substantia patris et spiritus sancti, sub unius censu totus subderetur mundus. Itaque haec natiuitas celebrata est prophetis praedicentibus et angelis proclamantibus Gloria in excelsis Deo, et in terra pax hominibus bonae uoluntatis, quando totus sub una pace mundus mirabili modo et praecedentibus saeculis inaudito quiescebat: quam uidelicet natiuitatem et pacem non solum diuini eloquii scripta, sed etiam gentilium oracula longe prius praedixerunt, ut in Sybillinis et ceterorum carminibus continetur.'

54 Cf. Jerome, Commentary on Isaiah I, ii. 4, ed. M. Adrian, CCSL 73 (Turnhout, 1963), p. 30.

"Frechulf, Histories I.2.5, p. 99 (Abraham); I.2.II, p. IO6 (Jacob); I.2.23, p. I29 (Deborah); I.7.I3, pp. 403-5 (Moses and Daniel). 
to Orosius, whose words he used to compare Abraham/Ninus with Christ/Augustus, but which paralleled an earlier excerpt from the City of God:

Thus it happened that when the blessed Abraham was born in the forty-second year under Ninus, the first king of the gentes, to whom divine promises were given and from whose seed Christ was promised to come forth, the birth of Christ took place almost at the end of the forty-second year [of Augustus]..$^{6}$

Orosius's Histories against the Pagans was perhaps not simply an 'indispensable complement to the City of God', as Hillgarth suggested, but for Frechulf both works were certainly compatible.

\section{Conclusion}

The respective emphases that the City of God and the Histories against the Pagans bestowed upon the coincidence of Christ's birth and the establishment of Augustus's global, irenic empire are taken to be characteristic of these works' stark differences. For Augustine, the coincidence was not stressed at all, whereas for his pupil it was absolutely central. ${ }^{57}$ The dichotomy that historians have posited between Augustine and Orosius has consequently shaped interpretations of Frechulf. When Staubach analysed the place of Augustus's empire within Frechulfs Augustinianinspired narrative, he detected a degree of ambivalence. Frechulf, he noted, seemingly saw Rome as nothing but a western Babylon whilst at the same time accepting the unambiguously providential significance of the empire granted to Augustus..$^{58}$

This ambivalence may in fact not be the result of any tension or contradiction perceived by Frechulf, but of modern historiographical traditions. ${ }^{59}$ If the Histories are approached from another angle, the tension fades. The central focus of Frechulf's Histories was not the Roman empire, but Christ and the demonstration that all history was providentially connected and conformed to God's plan for mankind's salvation. The 'truth of history' was bound intimately to the Nativity and the story of Christian salvation that was predicated upon it. For Frechulf, Augus-

56 Frechulf, Histories II.I.2, ed. Allen, p. 442; trans. Fear, Orosius, p. 322.

57 See for example Mommsen, 'Orosius and Augustine', pp. 34I, 346; W.H.C. Frend, 'Augustine and Orosius on the End of the Ancient World', Augustinian Studies 20 (1989), pp. I-38, at pp. 24-5; Inglebert, Les romains chrétiens, pp. 446-7, 493-4, 570-4.

58 Staubach, 'Christiana tempora', p. I88; Noble, Images, p. 353.

59 Cf. van Nuffelen, Orosius, p. 206. 
tine and Orosius - in their own different ways - presented not incompatible opinions about the Rome or the empire, but complementary perspectives onto the grand narrative of Christian history, in which Rome had an important part to play. ${ }^{60}$ Frechulf s Histories, therefore, show not so much what it might mean to be Roman after Rome, but reveal what Rome could mean to a Christian intellectual in the Carolingian empire.

Institut für Mittelalterforschung, Österreichische Akademie der Wissenschaften

6o See also Cinzia Gifroni's contribution to this issue. 